\title{
HIV screening among newly diagnosed TB patients: a cross sectional study in Lima, Peru
}

\author{
Suzanne Ramírez ${ }^{1}$, Fernando Mejía ${ }^{2,3}$, Marlene Rojas ${ }^{4}$, Carlos Seas ${ }^{1,2,3}$, Patrick Van der Stuyft ${ }^{5}$,
} Eduardo Gotuzzo ${ }^{1,2}$ and Larissa Otero ${ }^{1,2^{*}}$

\begin{abstract}
Background: Since 2006, the Peruvian National TB program (NTP) recommends voluntary counseling and testing (VCT) for all tuberculosis (TB) patients. Responding to the differential burden of both diseases in Peru, TB is managed in peripheral health facilities while HIV is managed in referral centers. This study aims to determine the coverage of HIV screening among TB patients and the characteristics of persons not screened.

Methods: From March 2010 to December 2011 we enrolled new smear-positive pulmonary TB adults in 34 health facilities in a district in Lima. NTP staff offered VCT to all TB patients. Patients with an HIV positive result were referred for confirmation tests and management. We interviewed patients to collect their demographic and clinical characteristics and registered if patients opted in or out of the screening.

Results: Of the 1295 enrolled TB patients, nine had a known HIV diagnosis. Of the remaining, 76.1\% (979) were screened for HIV. Among the 23.9\% (307) not screened, 38.4\% (118) opted out of the screening. TB patients at one of the health care facilities of the higher areas of the district $(\mathrm{OR}=3.38, \mathrm{Cl} 95 \%$ 2.17-5.28 for the highest area and $\mathrm{OR}=2.82, \mathrm{Cl} 95 \% 1$. 78-4.49 for the high area) as well as those reporting illegal drug consumption ( $\mathrm{OR}=1.65, \mathrm{Cl} 95 \%$ 1.15-2.37) were more likely not to be screened. Twenty-four were HIV positive (1.9\% of all patients 1295 , or $2.4 \%$ of those screened). Of 15 patients diagnosed with HIV during the TB episode, ten were enrolled in an HIV program. The median time between the result of the HIV screening and the first consultation at the HIV program was 82 days (IQR, 32-414). The median time between the result of the HIV screening and antiretroviral initiation was 148.5 days (IQR 32-500).
\end{abstract}

Conclusions: An acceptable proportion of TB patients were screened for HIV in Lima. Referral systems of HIV positive patients should be strengthened for timely ART initiation.

Keywords: Voluntary counseling testing, Tuberculosis, HIV, Peru

\section{Background}

In 2016, 1.3 million people died from tuberculosis (TB) and 1 million people died from HIV. Of the 10.4 million people that develop TB each year, one out of ten is HIV positive [1]. HIV is one of the most important challenges to $\mathrm{TB}$ control globally [2]. By severely affecting the

\footnotetext{
* Correspondence: Larissa.otero@upch.pe

${ }^{1}$ Facultad de Medicina Alberto Hurtado, Universidad Peruana Cayetano Heredia, Av. Honorio Delgado 430, San Martín de Porres, 31 Lima, Peru ${ }^{2}$ Instituto de Medicina Tropical Alexander von Humboldt, Universidad Peruana Cayetano Heredia, Av. Honorio Delgado 430, San Martín de Porres, 31 Lima, Peru

Full list of author information is available at the end of the article
}

immune system, HIV facilitates TB dissemination and increases mortality of coinfected persons as compared to TB patients who are HIV negative [2,3]. Active TB is an AIDS-defining disease and a criterion to start antiretroviral therapy (ART); therefore, diagnosis of both diseases is important in co-infected patients [4-8].

The optimal HIV screening strategy has been debated since the availability of HIV screening tests in 1985. Initially, HIV screening was mainly done in blood banks. In 1987, counseling and screening was recommended to persons at risk of HIV infection such as those with risk behaviors and those seeking care for sexually transmitted 
infections (STI). In 1993, screening was extended to patients attending hospitals that reported an HIV prevalence above 1\% among their patients. In 1995, learning that zidovudine could prevent HIV vertical transmission prompted the implementation of universal screening among pregnant women [9]. Despite these efforts, a low proportion of persons infected with HIV were aware of their status, and a high proportion of patients were diagnosed in late stages of HIV infection. To increase HIV diagnosis, a voluntary counseling and testing strategy required scaling up [10]. In 2005, the Center for Disease Control (CDC), recommended provider-initiated counseling and testing to all persons between 13 and 64 years unless the person opts out $[9,11]$. The World Health Organization (WHO) recommends HIV voluntary counseling and testing as a standard practice among TB patients to increase HIV status awareness [3]. However, in 2016 , the WHO estimated that $57 \%$ of notified cases of TB were aware of their HIV status [1].

In Peru, HIV is concentrated among high-risk groups and $0.4 \%$ of the general population is infected, on the other hand, TB burden is among the highest in the region: in 2016 the incidence for all TB cases was 117 per 100,000 population [1]. As the burden of TB is higher, case detection and treatment is conducted in the first level of health care. Conversely, because of its low prevalence, HIV/AIDS is managed in referral centers [12]. TB nurses working in peripheral health facilities offer voluntary counseling and testing for HIV of TB patients routinely. Peru adopted the HIV voluntary counseling and testing strategy among TB patients in 2006 [13]. The WHO reported that of the 31,079 TB patients notified in $2016,84 \%$ were screened for HIV. Of them, $6 \%$ were HIV positive [14]. TB-HIV co-infection is a challenge for public health, both for diagnosis and timely management and for the prognosis of both diseases. It is essential to expand HIV screening of TB patients and timely initiation of ART to improve individual prognosis, to reduce HIV transmission and to reduce the burden of HIV and TB. This study aims to determine the proportion of newly diagnosed TB patients screened for HIV in a district with high TB incidence in Lima, Peru and to analyze patient's and health system's characteristics associated to not being screened for HIV.

\section{Methods}

\section{Study design and setting}

We conducted a secondary data analysis of cross sectional data obtained within a cohort study in 34 health care facilities (one district hospital and 33 primary care health centers) managed by the Ministry of Health in the San Juan de Lurigancho district in Lima, Peru. This was a cohort study to determine the proportion of drug resistant $\mathrm{TB}$ and the rate of recurrent episodes among
TB patients. A sample size of 1130 was calculated for those objectives. Adults with a smear-positive pulmonary TB episode diagnosed between March 2010 and December 2011 with no history of previous TB treatment were enrolled. Patients initiated anti-TB treatment at the TB clinic and were followed at the health facility until the end of their treatment regimen. Treatment outcomes were prospectively obtained from the NTP registers. TB registers were monitored monthly up to two years after the end of treatment of the last enrolled case for TB recurrence. If a recurrent episode was found among an enrolled and cured TB patient, a sputum sample was collected $[15,16]$. San Juan de Lurigancho is a periurban district in the north east of Lima and lies on the side of a hill. It is the most populous district in Peru, with over one million inhabitants. In 2015, TB incidence in Lima was 164.9 per 100,000 inhabitants [17].

The NTP guidelines recommend that all TB patients should offered HIV screening with an ELISA or a rapid test after a pre test counseling session conducted by a TB nurse trained by the HIV program. A post test counseling session is given in referral health facilities where HIV multidisciplinary teams provide HIV care [18].

\section{Study participants}

The cohort study included consenting adult patients with a first episode of smear positive pulmonary TB diagnosed between March 2010 and December 2011 in one of the study sites. Patients that had received more than two doses of TB treatment were excluded. This secondary data analysis included all cohort participants.

\section{Study procedures}

Trained field workers enrolled participants and applied a structured questionnaire to collect demographic, epidemiological and clinical data. The variables sex, age, weight loss, education, social economical status, marital status, illegal drug consumption, alcohol abuse, history of deprivation of liberty, history of diabetes mellitus, employment and place of birth were obtained through face to face interviews while smear, culture and drug susceptibility test (DST) results, treatment outcomes, and HIV test results were retrieved from clinical files. A single sputum specimen was collected from each participant at enrollment. Sputa were transported to the Tuberculosis Laboratory of the Instituto de Medicina Tropical Alexander von Humboldt analyzed under smear microscopy and cultured on Löwenstein-Jensen media. The proportion methods evaluated drug susceptibility to isoniazid, rifampicin and ethambutol. Results were reported to the health facility $[15,16]$. The Tuberculosis Laboratory at the Instituto de Medicina Tropical Alexander von Humboldt conducted regular quality control assurance procedures for smear microscopy, culture and DST. 
Study participants that were not yet screened for HIV by the TB routine staff at the moment of the interview, were invited for screening. Those agreeing to be screened received counseling by the Ministry of Health designated staff and the study field workers drew a sample of blood. An ELISA or a rapid test was done. If positive, the diagnosis of HIV infection requires a confirmatory test (Indirect Immunofluorescence-IFI or Western Blot). ELISA for HIV was done at the Instituto de Medicina Tropical Alexander von Humboldt. Results were given to the TB staff that delivered the results to patients and managed them accordingly. Patients with a positive test (either obtained by the Ministry of Health routine procedures or by the study) were referred to HIV services (in Peru, these are located in referral hospitals) for a confirmatory test and post test counseling. If HIV was confirmed they were enrolled in the Ministry of Health HIV program where ART is provided free of cost to patients. The criteria to initiate ART [19] at the time of the study (2010-2011) were: Any symptomatic HIV-positive person with clinical stage $\mathrm{B}$ or $\mathrm{C}$ regardless CD4 count, any HIV-positive person with a CD4 count of 200 cells / mm3 regardless of clinical stage and other criteria determined by an expert committee. Clinical files of all TB-HIV positive patients were reviewed at the end of their TB treatment. We registered the date in which they were enrolled in the HIV program at the referral facility and the date of ART initiation.

For the cohort study logistics, the district was divided in four geographical areas depending on the altitude related to the hill of the study district and balancing the number and size of facilities in each area: highest, high, middle and lower. A field worker was assigned to each area. The two higher areas lie by the side of the hill that is less urbanized with poorer housing quality, and the middle area and lower areas, are on the flatter and more urban area of the district.

\section{Data management and analysis}

Data were entered in a specially designed database in Access for Microsoft Office (Microsoft Corporation, Redmond, WA, US) and analyzed using Epi Info ${ }^{\mathrm{TM}}$ version 7.1. The outcome was HIV screening (done or not done). Patients not screened were further categorized in "opted out" which included participants that explicitly opted out of HIV screening by saying "no, I do not want to be screened" and in "screening not done for unknown reasons" which included participants that did not explicitly opted out, but either HIV screening was not offered for unknown reasons or despite it being offered, it was not done for unknown reasons. This categorization aimed to compare the characteristics of patients optingout to those who did not explicitly opted out but screening not done for diverse reasons (patient may not want to be screened but does not say so, or he/she may want but it is not done, because of lack of follow up by the staff or other reasons). The hypothesis underlying this subclassification was that TB patients opting out of HIV screening may have a higher risk of HIV infection and fear of it makes them opt out. While this hypothesis cannot be confirmed in this study, a comparison of patients opting out with those not screened without explicitly opting out, could be relevant. Age was categorized in young adults (18-34 years), adults (35-59 years) and older adults (60-90 years). The 22-months study period was divided in four periods to determine time trends in HIV screening. HIV screening could be different in time if there were screening tests stock outs, or if staff changes in time affected performance related to HIV screening. Socioeconomic status was measured by a Peruvian Ministry of Finance validated scale and categorized patients in poor (including extreme and not extreme poverty) and not poor [20]. Alcohol consumption was measured using the validated CAGE four-question screening test [21]. Those that had a high suspicion of alcoholism we classified as alcoholics.

We developed contingency tables to compare the independent variables with the outcome. Three bivariate analyses of independent variables and outcomes were done: being screened versus not being screened, which included all patients enrolled; refusing screening versus not being screening for unknown reasons, which included patients that were not screened; and HIV positive versus negative, which included all those screened. Odds ratios (OR) were calculated with 95\% confidence intervals (CI). Two multivariate models were constructed using logistic regression, one for predictors of being screened for HIV, and one for predictors of opting out among those not screened for HIV. Both multivariate analyses were done in a stepwise backward manner. Variables associated with the outcome at a $p<0.2$ significance as well as others relevant for each of the two outcomes were included in the multivariate model. We excluded missing data in the analysis of the determinants of not being screened for HIV. We included 1197 patients (98 were excluded for missing data: 88 on socio economic status and 10 for all other independent variables) in the multivariable model.

\section{Results}

Study population and HIV prevalence among TB patients The cohort study included 1295 patients and all were included in our analysis. Figure 1 describes the study population, those screened for HIV and the HIV screening results. Nine were aware of their HIV positive status before the TB diagnosis and fifteen were diagnosed with HIV during the TB episode. HIV prevalence was $1.9 \%(24 / 1295)$ among all TB patients, 


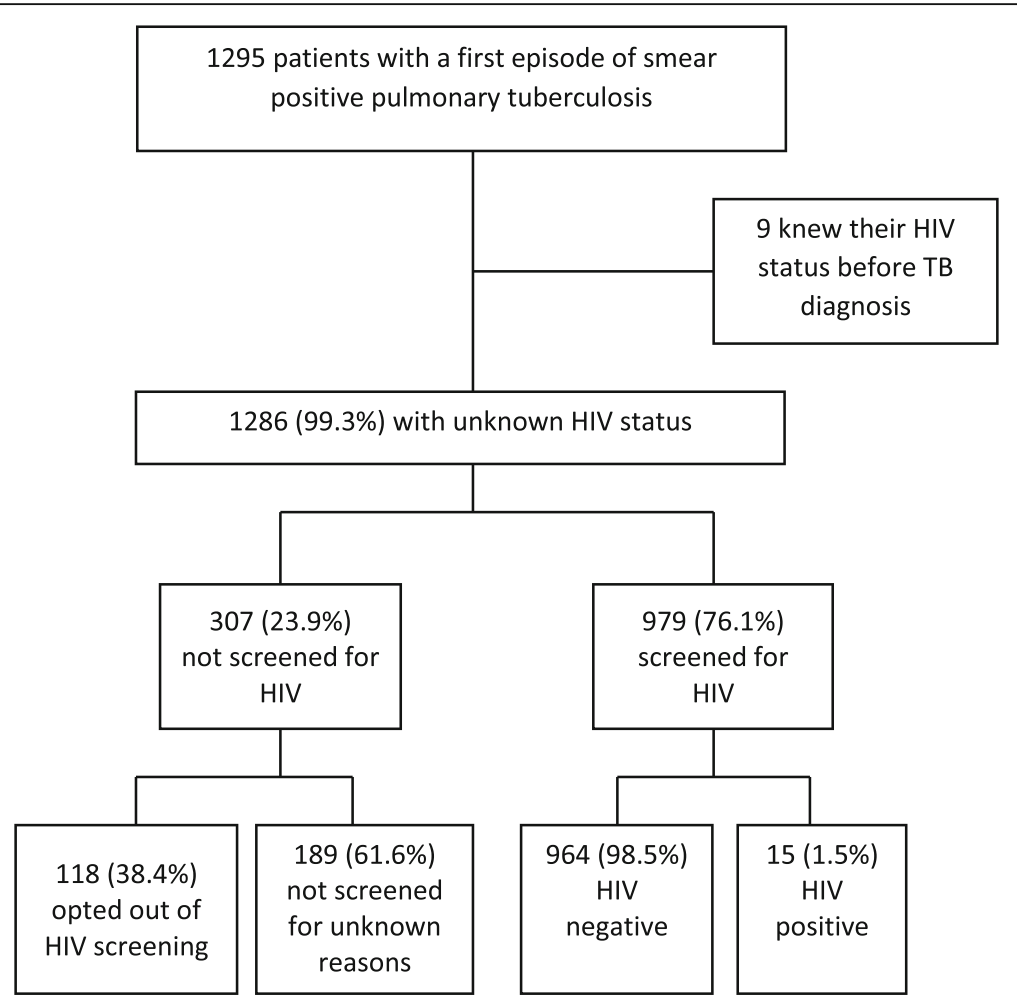

Fig. 1 Patients with a first episode of tuberculosis and HIV screening in San Juan de Lurigancho, 2010-2011

while it was $2.4 \%(24 / 988)$ among those with a known HIV status (excluding those not tested).

\section{HIV screening coverage and determinants of screening}

Of all HIV screenings conducted among the study participants $(76.1 \%, 979 / 1286): 81.2 \%$ (795/979) were done by the routine TB staff, $18.8 \%(184 / 979)$ were done by the study field workers. Therefore, if the study staff had not conducted additional efforts to those of the routine staff to screen TB patients for HIV, coverage of HIV screening among new TB patients would have been $61.8 \%$ (795/1286). Table 1 describes the characteristics of patients that were screened, of those opting out and of those not screened for unknown reasons.

Among those screened for HIV, the median time between TB treatment initiation and HIV screening was 4 days (interquartile range $0-18$ days). In 69.9\% (684/979) patients, HIV screening was done before or within 15 days after TB treatment initiation -as per NTP guidelines- and after 15 days of starting TB treatment in 30.1\% (295/979) patients.

Table 2 shows the determinants of not being screened for HIV of the 1197 patients included in the analysis (98 were excluded for missing data: 88 on socio economic status and 10 on a single other variable). Receiving $\mathrm{TB}$ care in one of the health care facilities of the higher areas of the district (odds ratio $(\mathrm{OR})=3.38$, confidence interval (CI) $95 \% 2.17-5.28, p<0.0001$ for the highest area and $\mathrm{OR}=2.82$, CI 95\% 1.78-4.49, $p<0001$, for the high area) as well as reporting illicit drug consumption $(\mathrm{OR}=1.65$, CI 95\% 1.15-2.37, $p=0.0062)$ was associated to not being screened for HIV.

Table 3 compares the characteristics of patients opting out of HIV screening to those of patients not screened for unknown reasons. Attending a health care facility in the highest area of the district was associated to opting out of screening. Patients reporting illegal drug consumption and those enrolled in the third period of the study were more likely not to be screened because of unknown reasons as compared to opting out of screening.

\section{Determinants and management of HIV positive TB patients}

In a bivariate analysis of the characteristics of HIV positivity (including both those diagnosed before the TB episode and those diagnosed during the TB episode) among the 988 patients screened, more men than women were HIV positive $(18(3.0 \%)$ vs. $6(1.5 \%))$, more adults than young adults $(9(4.3 \%)$ vs. and $15(2.0 \%))$ and more patients reporting illegal drug consumption were HIV positive than those reporting never having used illegal drugs (crude OR: 4.24, 95\%CI 1.85-9.73). We had insufficient power to conduct a multivariate analysis of predictors of HIV positive status. 
Table 1 Characteristics of patients with a first episode of tuberculosis by their HIV screening status, San Juan de Lurigancho, 2010-2011

\begin{tabular}{|c|c|c|c|}
\hline Characteristics & Screened & $\begin{array}{l}\text { Not screened for } \\
\text { unknown reasons }\end{array}$ & Opted out of screening \\
\hline & $N(\%)$ & $N(\%)$ & $N(\%)$ \\
\hline \multicolumn{4}{|l|}{ Sex } \\
\hline Female & $394(39.9 \%)$ & $69(36.3 \%)$ & $39(33.1 \%)$ \\
\hline Male & $593(60.1 \%)$ & $121(63.7 \%)$ & $79(66.9 \%)$ \\
\hline \multicolumn{4}{|l|}{ Age, in years } \\
\hline $18-34$ & $721(73.0 \%)$ & $137(72.1 \%)$ & $83(71.0 \%)$ \\
\hline $35-49$ & $210(21.3 \%)$ & $41(21.6 \%)$ & $24(20.5 \%)$ \\
\hline$>50$ & $57(5.7 \%)$ & $12(6.3 \%)$ & $10(8.5 \%)$ \\
\hline \multicolumn{4}{|l|}{ Weight loss reported by the patient } \\
\hline Yes & $798(81.1 \%)$ & $162(85.3 \%)$ & $94(79.7 \%)$ \\
\hline No & $186(18.9 \%)$ & $28(14.7 \%)$ & $24(20.3 \%)$ \\
\hline \multicolumn{4}{|c|}{ Location of health facility in district area } \\
\hline Lowest area & 199 (20.2\%) & $25(13.2 \%)$ & $8(6.8 \%)$ \\
\hline Middle area & $314(31.8 \%)$ & $35(18.4 \%)$ & $12(10.2 \%)$ \\
\hline Highest area & $259(26.2 \%)$ & $73(38.4 \%)$ & $63(53.4 \%)$ \\
\hline High area & $215(21.8 \%)$ & $57(30.0 \%)$ & $35(29.6 \%)$ \\
\hline \multicolumn{4}{|l|}{ Education } \\
\hline Primary school or less & $400(40.6 \%)$ & $87(45.8 \%)$ & $60(50.8 \%)$ \\
\hline High school & $365(37.0 \%)$ & $67(35.3 \%)$ & $36(30.6 \%)$ \\
\hline Higher education & $221(22.4 \%)$ & $36(18.9 \%)$ & $22(18.6 \%)$ \\
\hline \multicolumn{4}{|l|}{ Socioeconomic status } \\
\hline Poor & $240(26.0 \%)$ & $48(27.3 \%)$ & $30(28.3 \%)$ \\
\hline Not poor & $685(74.0 \%)$ & $128(72.7 \%)$ & $76(71.7 \%)$ \\
\hline \multicolumn{4}{|l|}{ Marital status } \\
\hline Married / cohabiting & $369(37.4 \%)$ & $65(34.3 \%)$ & $53(45.0 \%)$ \\
\hline Divorced & $72(7.3 \%)$ & $16(8.4 \%)$ & $5(4.2 \%)$ \\
\hline Single & $521(52.8 \%)$ & $101(53.1 \%)$ & $56(47.5 \%)$ \\
\hline Widow & $25(2.5 \%)$ & $8(4.2 \%)$ & $4(3.3 \%)$ \\
\hline \multicolumn{4}{|l|}{ Illegal drug consumption } \\
\hline No & $838(84.9 \%)$ & $140(73.7 \%)$ & $99(83.9 \%)$ \\
\hline Yes & 149 (15.1\%) & $50(26.3 \%)$ & $19(16.1 \%)$ \\
\hline \multicolumn{4}{|l|}{ Alcohol consumption (CAGE score) } \\
\hline Alcoholism & $52(8.9 \%)$ & $13(10.7 \%)$ & $7(9.3 \%)$ \\
\hline No alcoholism & $534(91.1 \%)$ & 109 (89.3\%) & $68(90.7 \%)$ \\
\hline \multicolumn{4}{|l|}{ Ex prison inmate } \\
\hline Yes & $49(5.0 \%)$ & $8(4.2 \%)$ & $4(3.4 \%)$ \\
\hline No & $936(95.0 \%)$ & $182(95.8 \%)$ & $114(96.6 \%)$ \\
\hline \multicolumn{4}{|c|}{ Diabetes mellitus, as reported by the patient } \\
\hline Yes & $41(4.2 \%)$ & $9(4.7 \%)$ & $5(4.2 \%)$ \\
\hline No & $944(95.8 \%)$ & $181(95.3 \%)$ & $113(95.8 \%)$ \\
\hline \multicolumn{4}{|l|}{ Type of TB treatment regimen } \\
\hline Regimen for drug sensitive TB & $970(98.3 \%)$ & 189 (99.5\%) & $116(98.3 \%)$ \\
\hline Regimens for drug resistant TB & $17(1.7 \%)$ & $1(0.5 \%)$ & $2(1.7 \%)$ \\
\hline
\end{tabular}


Table 1 Characteristics of patients with a first episode of tuberculosis by their HIV screening status, San Juan de Lurigancho, 2010-2011 (Continued)

\begin{tabular}{llll}
\hline Characteristics & Screened & $\begin{array}{l}\text { Not screened for } \\
\text { unknown reasons }\end{array}$ & Opted out of screening \\
\hline $\begin{array}{l}\text { Employment } \\
\text { Yes }\end{array}$ & $695(70.4 \%)$ & $138(72.6 \%)$ & $83(70.3 \%)$ \\
No & $190(19.3 \%)$ & $40(21.1 \%)$ & $21(17.8 \%)$ \\
Student & $102(10.3 \%)$ & $12(6.3 \%)$ & $14(11.9 \%)$ \\
Study period & & & $34(28.8 \%)$ \\
1 & $261(26.4 \%)$ & $39(20.5 \%)$ & $28(23.7 \%)$ \\
2 & $233(23.6 \%)$ & $42(22.1 \%)$ & $18(15.3 \%)$ \\
3 & $258(26.2 \%)$ & $64(33.7 \%)$ & $38(32.2 \%)$ \\
4 & $235(23.8 \%)$ & $45(23.7 \%)$ & $74(62.7 \%)$ \\
Place of birth & & $116(61.1 \%)$ & $19(16.1 \%)$ \\
Coastal region & $611(62.0 \%)$ & $27(14.2 \%)$ & $25(21.2 \%)$ \\
Jungle region & $138(14.0 \%)$ & $47(24.7 \%)$ & \\
Andean region & $237(24.0 \%)$ & & \\
\hline
\end{tabular}

Of the nine patients known to be HIV positive before the TB episode, eight were already on ART. Of the 15 patients diagnosed with HIV during the TB episode, we found evidence that 10 were affiliated to the Ministry of Health HIV program at a referral hospital and 9 were started on ART. We did not find evidence of HIV program enrollment in five patients. These patients may have been enrolled in an HIV program without it being registered in their TB clinical files, they may have attended a private HIV care facility where they have to pay for care and ART, or they may have not been enrolled in an HIV program. The median time between the result of the HIV screening and the first medical consultation of the HIV program, among those 10 patients, was 82 days (IQR, 32-414). The median time between the result of the HIV screening and ART initiation was 148.5 days (IQR, 32-500). The median CD4 cell count among patients enrolled in HIV care during the TB episode was 189 cells/mm³ (IQR, 55-312).

\section{Discussion}

We found an HIV screening coverage of $76.1 \%$ among patients recently diagnosed with smear positive pulmonary TB in an urban context of median TB incidence and low HIV prevalence. Factors associated to not being screened were illegal drug consumption and geographical location of the TB health facility within the study district. Fifteen TB patients were diagnosed with HIV during the TB episode, of which five did not have evidence of HIV program enrollment upon completion of TB treatment.

In the Americas region, in 2016, 80\% persons notified for TB had a documented HIV positive test result, which is above the global proportion for 2016 (57\%). In the same year, HIV screening in Peru covered $84 \%$ of TB patients [14]. In 2010 (when our study was conducted) the National TB Program reported that $76 \%$ of TB patients were screened for HIV [22]. In our study, conducted between 2010 and 2011, we found a fairly high coverage, however, the study staff did additional efforts to screen those that had not being initially screened.

Only 9.2\% TB patients opted out of screening, while $14.7 \%$ were not screened for unknown reasons. Patients not screened without explicitly opting out may have not wanted to be screened but did not say so, or the screening may have been delayed or postponed for diverse reasons (patient's reasons such as not being sure, or fearing HIV screening, or health system reasons such as inadequate follow up of screening request). In South Africa, voluntary counseling and testing was adopted in 2007 but less than half of the TB patient's accepted HIV screening [23]. In India, $60 \%$ of $\mathrm{TB}$ patients were screened for HIV and 33\% of new HIV diagnoses would have been missed if screening during the TB episode were not done [24].

Our finding that living in the higher areas of the district that lie by the hill as opposed to living in the middle and lower areas that are more urbanized, was associated to not being screened. Also, those living in the highest area were more likely to opt out of screening. This may be due to the fact that in higher areas of the district there are fewer health centers and road access may be more difficult. This area of the district has lower socioeconomic status, however, the association we found was independent of that factor and of level of education of the patient. This suggests that health care facilityrelated factors not measured in this study could be associated to screening coverage. Management of health 
Table 2 Determinants of not being screened for HIV among 1197 patients with a first episode of smear positive pulmonary tuberculosis, San Juan de Lurigancho, 2010-2011

\begin{tabular}{|c|c|c|c|c|c|c|}
\hline Characteristics & $\begin{array}{l}\text { Screened } \\
N(\%)\end{array}$ & $\begin{array}{l}\text { Not screened } \\
N(\%)\end{array}$ & Crude OR (95\% Cl) & $p$ & Adjusted OR (95\%Cl) & $p$ \\
\hline \multicolumn{7}{|l|}{ Sex } \\
\hline Female & $394(78.5 \%)$ & $108(21.5 \%)$ & 1 & & & \\
\hline Male & $593(74.8 \%)$ & $200(25.2 \%)$ & $1.23(0.94-1.63)$ & 0.136 & & \\
\hline \multicolumn{7}{|l|}{ Age, in years } \\
\hline $18-34$ & $721(76.6 \%)$ & $220(23.4 \%)$ & $0.94(0.68-1.31)$ & 0.752 & & \\
\hline $35-49$ & $210(76.4 \%)$ & 65 (23.6\%) & 1 & & & \\
\hline$>50$ & $57(72.1 \%)$ & 22 (27.9\%) & $1.15(0.63-2.09)$ & & & \\
\hline \multicolumn{7}{|l|}{$\begin{array}{l}\text { Weight loss reported } \\
\text { by the patient }\end{array}$} \\
\hline Yes & $798(75.7 \%)$ & $256(24.3 \%)$ & $1.07(0.76-1.51)$ & 0.699 & & \\
\hline No & $186(78.2 \%)$ & $52(21.8 \%)$ & 1 & & & \\
\hline \multicolumn{7}{|l|}{$\begin{array}{l}\text { Location of health } \\
\text { facility in district area }\end{array}$} \\
\hline Lowest area & $199(85.8 \%)$ & $33(14.2 \%)$ & 1 & & 1 & \\
\hline Middle area & $314(87.0 \%)$ & 47 (13.0\%) & $0.89(0.54-1.47)$ & & $0.90(0.54-1.49)$ & $<0.001$ \\
\hline Highest area & $259(65.6 \%)$ & $136(34.4 \%)$ & $3.34(2.15-5.21)$ & & $3.38(2.17-5.28)$ & \\
\hline High area & $215(70.0 \%)$ & $92(30.0 \%$ & $2.8(1.77-4.45)$ & $<0.001$ & $2.82(1.78-4.49)$ & \\
\hline \multicolumn{7}{|l|}{ Education } \\
\hline Primary or less & $400(73.1 \%)$ & 147 (26.9\%) & $1.23(0.91-1.66)$ & 0.153 & & \\
\hline High School & 365 (78.0\%) & $103(22.0 \%)$ & 1 & & & \\
\hline Higher & $221(79.2 \%)$ & $58(20.8 \%)$ & $0.88(0.61-1.28)$ & & & \\
\hline \multicolumn{7}{|l|}{ Socioeconomic status } \\
\hline Poor & $240(75.5 \%)$ & 78 (24.5\%) & $1.09(0.81-1.48)$ & 0.556 & & \\
\hline Not poor & $685(77.0 \%)$ & $204(23 \%)$ & 1 & & & \\
\hline \multicolumn{7}{|l|}{ Marital Status } \\
\hline Married / cohabiting & $369(75.8 \%)$ & $118(2.2 \%)$ & $1.12(0.84-1.49)$ & 0.523 & & \\
\hline Divorced & 72 (77.4\%) & $21(22.6 \%)$ & $0.88(0.51-1.53)$ & & & \\
\hline Single & $521(76.8 \%)$ & $157(23.2 \%)$ & 1 & & & \\
\hline Widow & $25(67.6 \%)$ & $12(32.4 \%)$ & $1.57(0.75-3.29)$ & & & \\
\hline \multicolumn{7}{|l|}{ Illegal drug consumption } \\
\hline Yes & $149(68.3 \%)$ & 69 (31.7\%) & $1.64(1.16-2.32)$ & 0.006 & $1.65(1.15-2,37)$ & 0.006 \\
\hline No & $838(77.8 \%)$ & $239(22.2 \%)$ & 1 & & 1 & \\
\hline \multicolumn{7}{|l|}{$\begin{array}{l}\text { Alcohol consumption } \\
\text { (CAGE score) }\end{array}$} \\
\hline Yes & $52(72.2 \%)$ & $20(27.8 \%)$ & $1.28(0.74-2.22)$ & 0.38 & & \\
\hline No & $534(75.1 \%)$ & 177 (24.9\%) & 1 & & & \\
\hline \multicolumn{7}{|l|}{ Ex prison inmate } \\
\hline Yes & 49 (80.3\%) & $12(19.7 \%)$ & $0.68(0.31-1.47)$ & 0.305 & & \\
\hline No & $936(76.1 \%)$ & $296(23.9 \%)$ & 1 & & & \\
\hline \multicolumn{7}{|l|}{$\begin{array}{l}\text { Diabetes Mellitus, as } \\
\text { reported by the patient }\end{array}$} \\
\hline Yes & $41(74.5 \%)$ & $14(25.5 \%)$ & $1.12(0.60-2.08)$ & 0.725 & & \\
\hline No & $944(76.3 \%)$ & $294(23.7 \%)$ & 1 & & & \\
\hline
\end{tabular}


Table 2 Determinants of not being screened for HIV among 1197 patients with a first episode of smear positive pulmonary tuberculosis, San Juan de Lurigancho, 2010-2011 (Continued)

\begin{tabular}{|c|c|c|c|c|c|c|}
\hline Characteristics & $\begin{array}{l}\text { Screened } \\
N(\%)\end{array}$ & $\begin{array}{l}\text { Not screened } \\
N(\%)\end{array}$ & Crude OR (95\% Cl) & $p$ & Adjusted OR $(95 \% \mathrm{Cl})$ & $p$ \\
\hline \multicolumn{7}{|l|}{ TB regimen } \\
\hline Regimen for drug sensitive TB & $970(76.1 \%)$ & $305(23.9 \%)$ & 1 & & & \\
\hline Regimens for drug resistant TB & $17(85.0 \%)$ & $3(15 \%)$ & $0.70(0.20-2.44)$ & 0.556 & & \\
\hline \multicolumn{7}{|l|}{ Employment } \\
\hline Yes & $695(75.8 \%)$ & $221(24.2 \%)$ & 1 & 0.646 & & \\
\hline No & $190(75.7 \%)$ & $61(24.3 \%)$ & $0.99(0.71-1.40)$ & & & \\
\hline Student & $102(79.7 \%)$ & $26(20.3 \%)$ & $0.81(0.50-1.28)$ & & & \\
\hline \multicolumn{7}{|l|}{ Study Period } \\
\hline 1 & $261(78.1 \%)$ & $73(21.9 \%)$ & 1 & & & \\
\hline 2 & $233(76.9 \%)$ & $70(23.1 \%)$ & $1.13(0.76-1.67)$ & 0.431 & & \\
\hline 3 & $258(75.9 \%)$ & $82(24.1 \%)$ & $1.18(0.80-1.73)$ & & & \\
\hline 4 & $235(74.0 \%)$ & $83(26.0 \%)$ & $1.37(0.94-2.01)$ & & & \\
\hline \multicolumn{7}{|l|}{ Place of birth } \\
\hline Coastal region & $611(76.3 \%)$ & $190(23.7 \%)$ & 1 & 0.985 & & \\
\hline Jungle region & $138(75.0 \%)$ & $46(25.0 \%)$ & $0.97(0.65-1.44)$ & & & \\
\hline Andean region & 237 (76.7\%) & 72 (23.3\%) & $0.98(0.71-1.35)$ & & & \\
\hline
\end{tabular}

facilities in Lima is organized in micronetworks within districts. There may be characteristics of these micronetworks in the higher area that do not favor screening, such as number of health staff dedicated to TB activities and poorer supervision practices. This should be further explored in future studies.

The single patient related factor -among those measured by the study- associated to not being screened was illegal drug consumption. The screening strategy in this group (17\% of the TB patients in our study reported use of illegal drugs) should be reinforced. The use of any illegal drug is associated with risk behaviors that may increase the likelihood of acquiring or transmitting HIV infection. In South Africa, fear, low perception of risk and the wish of being treated first and only for TB as well as not being offered screening, was associated to not been screened for HIV [25]. In a similar study in India, uptake of HIV testing was significantly lower in older age groups and females [26]. In Cambodia, married patients, those with a previous HIV screening, a higher level of education and with more access to a health facility were more likely to be screened while self-perceived stigma was associated to not being screened [27]. Peru is a country with a median TB incidence and a concentrated HIV epidemic, but co-infection has increased in recent years. Despite the fact that since 2013, the NTP recommends that every patient diagnosed with TB have to be screened for HIV, $100 \%$ screening coverage has not yet been reached.
Our findings suggest the need of strengthening the reference systems between TB and HIV programs. Despite having a small number of HIV positive patients, we detected a delay between HIV positive result and HIV program enrollment and ART initiation, and we did not find evidence of HIV program enrollment in five patients. The HIV and TB program in Peru are partially integrated but care for both infections is provided in different facilities. Obtaining an appointment at referral hospitals in Lima, where HIV diagnosis is confirmed and managed, can take long and that could be contributing to the delays found [28]. Stigma has been cited in other settings as a cause that discouraged rapid linkage to care of recently diagnosed HIV-positive individuals [29]. Prompt linkage to care for early ART initiation is important to achieve rapid virologic suppression and reduce mortality [30, 31]. A better integration of both programs could reduce barriers [32-34] for timely care and facilitate the initiation of ART. Decentralizing HIV care to peripheral health facilities where TB is managed may facilitate geographical access. Yet, if peripheral facilities are located at the patient's neighborhoods it may increase stigma and fear of disclosure of HIV diagnosis.

This operational study has some limitations. We did not obtain the exact reasons for why patients refused screening or why it was not done among those not opting out, which impedes a more precise explanation to our findings. Furthermore, we do not know which would 
Table 3 Determinants of opting out of HIV screening as compared to not being screened for unknown reasons in 307 smear positive tuberculosis patients not screened for HIV, San Juan de Lurigancho 2010-2011

\begin{tabular}{|c|c|c|c|c|c|}
\hline Characteristics & $\begin{array}{l}\text { Opted out of } \\
\text { screening } \\
N(\%)\end{array}$ & $\begin{array}{l}\text { Not screened for } \\
\text { unknown reasons } \\
N(\%)\end{array}$ & $\begin{array}{l}\text { Crude OR } \\
(95 \% \mathrm{Cl})\end{array}$ & $p$ & Adjusted OR (95\%Cl) \\
\hline \multicolumn{6}{|l|}{ Sex } \\
\hline Female & $39(36.2 \%)$ & $69(63.8 \%)$ & 1 & & \\
\hline Male & $79(39.5 \%)$ & $121(60.5 \%)$ & $1.14(0.70-1.85)$ & 0.595 & \\
\hline \multicolumn{6}{|l|}{ Age, in years } \\
\hline $18-34$ & $83(37.7 \%)$ & $137(62.27 \%)$ & $1.04(0.58-1.84)$ & 0761 & \\
\hline $35-49$ & $24(36.9 \%)$ & $41(63.1 \%)$ & 1 & & \\
\hline$>50$ & $10(45.5 \%)$ & $12(54.5 \%)$ & $1.42(0.53-3.79)$ & & \\
\hline \multicolumn{6}{|l|}{ Weight loss reported by the patient } \\
\hline Yes & $94(36.7 \%)$ & $162(63.3 \%)$ & $0.67(0.37-1.22)$ & 0.194 & \\
\hline No & $24(46,2 \%)$ & $28(53.8 \%)$ & 1 & & \\
\hline \multicolumn{6}{|c|}{ Location of health facility in district area } \\
\hline Lowest area & $8(24.2 \%)$ & $25(75.8 \%)$ & 1 & & 1 \\
\hline Middle area & $12(25.5 \%)$ & $35(74.5 \%)$ & $1.07(0.38-3.00)$ & 0.022 & $1.21(0.42-3.49)$ \\
\hline Highest area & $63(46.3 \%)$ & $73(53.7 \%)$ & $2.65(1.12-6.30)$ & & $3.28(1.32-8.18)$ \\
\hline High area & $35(38.0 \%)$ & $57(62.0 \%)$ & $1.92(0.78-4.72)$ & & $2.18(0.86-5.56)$ \\
\hline \multicolumn{6}{|l|}{ Education } \\
\hline Primary or less & $60(40.8 \%)$ & $87(59.2 \%)$ & $1.28(0.76-2.16)$ & 0.627 & \\
\hline High School & $36(35 \%)$ & $67(65.0 \%)$ & 1 & & \\
\hline Higher & $22(37.9 \%)$ & $36(62.1 \%)$ & $1.09(0.55-2.13)$ & & \\
\hline \multicolumn{6}{|l|}{ Marital Status } \\
\hline Married / cohabiting & $53(44.9 \%)$ & $65(55.1 \%)$ & $1.44(0.88-2.35)$ & 0.219 & \\
\hline Divorced & $5(23.8 \%)$ & $16(76.2 \%)$ & $0.56(0.20-1.62)$ & & \\
\hline Single & $56(35.7 \%)$ & $101(64.3 \%)$ & 1 & & \\
\hline Widow & $4(33.3 \%)$ & $8(66.7 \%)$ & $0.90(0.26-3.13)$ & & \\
\hline \multicolumn{6}{|l|}{ Illegal drug consumption } \\
\hline Yes & $19(27.5 \%)$ & $50(72.5 \%)$ & $0.54(0.30-0.98)$ & 0.037 & $0.43(0.23-0.80)$ \\
\hline No & $99(41.4 \%)$ & $140(58.6 \%)$ & 1 & & \\
\hline \multicolumn{6}{|l|}{ Alcohol consumption (CAGE score) } \\
\hline Yes & $7(35.0 \%)$ & $13(65.0 \%)$ & $0.74(0.29-1.88)$ & 0.524 & \\
\hline No & $68(38.4 \%)$ & $109(61.6 \%)$ & 1 & & \\
\hline \multicolumn{6}{|l|}{ Ex prison inmate } \\
\hline Yes & $4(46.7 \%)$ & $8(53.3 \%)$ & $0.81(0.24-2.74)$ & 0.726 & \\
\hline No & $114(38.5 \%)$ & $182(61.5 \%)$ & 1 & & \\
\hline \multicolumn{6}{|c|}{ Diabetes Mellitus, as reports by the patient } \\
\hline Yes & $5(35.7 \%)$ & $9(64.3 \%)$ & $0.90(0.29-2.75)$ & 0.849 & \\
\hline No & $113(38.4 \%)$ & $181(61.6 \%)$ & 1 & & \\
\hline \multicolumn{6}{|l|}{ TB regimen } \\
\hline Regimen for drug sensitive TB & $116(38.0 \%)$ & $189(62.0 \%)$ & 1 & & \\
\hline Regimens for drug resistant TB & $2(66.7 \%)$ & 1 (33.3\%) & $3.29(0.29-36.6)$ & 0.315 & \\
\hline \multicolumn{6}{|l|}{ Employment } \\
\hline Yes & $83(37.6 \%)$ & $138(62.4 \%)$ & 1 & & \\
\hline
\end{tabular}


Table 3 Determinants of opting out of HIV screening as compared to not being screened for unknown reasons in 307 smear positive tuberculosis patients not screened for HIV, San Juan de Lurigancho 2010-2011 (Continued)

\begin{tabular}{|c|c|c|c|c|c|c|}
\hline Characteristics & $\begin{array}{l}\text { Opted out of } \\
\text { screening } \\
N(\%)\end{array}$ & $\begin{array}{l}\text { Not screened for } \\
\text { unknown reasons } \\
N(\%)\end{array}$ & $\begin{array}{l}\text { Crude OR } \\
(95 \% \mathrm{Cl})\end{array}$ & $p$ & Adjusted OR (95\%Cl) & $\bar{p}$ \\
\hline No & $21(34.4 \%)$ & $40(65.6 \%)$ & $0.88(0.49-1.60)$ & 0.217 & & \\
\hline Student & $14(53.8 \%)$ & $12(46.2 \%)$ & $1.96(0.87-4.45)$ & & & \\
\hline \multicolumn{7}{|l|}{ Study Period } \\
\hline 1 & $34(46.6 \%)$ & 39 (53.4\%) & 1 & & 1 & \\
\hline 2 & $28(40.0 \%)$ & $42(60.0 \%)$ & $0.79(0.40-1.53)$ & 0.003 & $0.65(0.33-1.31)$ & \\
\hline 3 & $18(22.0 \%)$ & $64(78.0 \%)$ & $0.33(0.17-0.67)$ & & $0.23(0.11-0.49)$ & \\
\hline 4 & $38(45.8 \%)$ & 45 (54.2\%) & $0.99(0.53-1.88)$ & & $0.71(0.35-1.40)$ & \\
\hline \multicolumn{7}{|l|}{ Place of birth } \\
\hline Coastal region & $74(39.0 \%)$ & $116(61.0 \%)$ & 1 & & & \\
\hline Jungle region & $19(41.3 \%)$ & 27 (58.7\%) & $1.10(0.57-2.12)$ & 0.663 & & \\
\hline Andean region & $25(34.7 \%)$ & 47 (65.3\%) & $0.80(0.45-1.42)$ & & & \\
\hline
\end{tabular}

have been the coverage if the study were not conducted. As we made additional efforts to those of the routine staff to screen patients for HIV, we probably overestimated the routine coverage. However, the coverage reported by this study, reflects the potential reach of HIV screening if it is systematically offered to all TB patients. We did not collect risk factors for HIV infection. If we had collected risk factors for HIV infection, we could compare the presence of risk factors among the patients screened, those that opted out and those that were not screened for unknown reasons. Opting out of HIV screening could result from a very low perception of risk or form fear of a positive result because of risk behavior. In studies in Ethiopia and South Africa, adults with TB thought that voluntary counseling and testing could delay TB treatment and that TB treatment should be prioritized [35]. Finally, the small number of HIV TB co-infected patients did not allow a multivariate analysis to predict HIV infection among TB patients. Among the strengths of the study was that it included a large number of TB patients representative of the TB population in the district.

\section{Conclusions}

We found that $76.1 \%$ patients recently diagnosed with TB, were screened for HIV. Patients that reported illegal drug use were less likely to be screened. Patients with a recent HIV diagnosis took long to be enrolled in a program for the initiation of antiretroviral treatment. This suggests a suboptimal integration of TB and HIV services since $\mathrm{TB}$ is managed in primary care centers and HIV is managed in referral centers such as hospitals. Most studies on HIV screening among TB patients are from countries with high HIV prevalence. HIV screening and management among TB patients in settings with low HIV prevalence (less than 1\%), such as Peru should be enhanced to reduce mortality from co-infection.

\section{Abbreviations}

ART: antiretrovirals; Cl: Confidence Interval; HIV: Human Immunodeficiency Virus; NTP: National Tuberculosis Program; TB: Tuberculosis

\section{Acknowledgements}

We acknowledge the district TB staff and the study field workers for their collaboration with the study.

\section{Funding}

This study was funded by the Belgian Cooperation through a Framework Agreement project of institutional collaboration between the Institute of Tropical Medicine in Antwerp, Belgium and the Instituto de Medicina Tropical Alexander von Humboldt in Lima, Peru and through the Peru PARACAS: Program for Advanced Research Capacities for AIDS in Peru Research Training National Institutes of Health (grant 1D43TW009763-01) The funders had no role in study design, data collection and analysis, decision to publish, or preparation of the manuscript.

\section{Availability of data and materials}

The data that support the findings of this study are available on request to the authors.

\section{Authors' contributions}

Conception and design of the work: SR, CS, PVDS, EGH, LO. Implementation: LO, MR, CS, PVDS. Data analysis: SR, FM, LO. Data interpretation, critical revision and important intellectual input: SR, FM, MR, CS, PVDS, EGH, LO. First draft: SR. All authors approved the final version to be published.

\section{Ethics approval and consent to participate}

The protocol was approved by the Institutional Ethics Committees from the Universidad Peruana Cayetano Heredia. All participants signed an informed consent and received a copy of it. Participants that were screened for HIV by the study staff signed an additional informed consent.

Consent for publication

Not applicable.

Competing interests

The authors declare that they have no competing interests. 


\section{Publisher's Note}

Springer Nature remains neutral with regard to jurisdictional claims in published maps and institutional affiliations.

\section{Author details \\ ${ }^{1}$ Facultad de Medicina Alberto Hurtado, Universidad Peruana Cayetano Heredia, Av. Honorio Delgado 430, San Martín de Porres, 31 Lima, Peru. ${ }^{2}$ Instituto de Medicina Tropical Alexander von Humboldt, Universidad Peruana Cayetano Heredia, Av. Honorio Delgado 430, San Martín de Porres, 31 Lima, Peru. ${ }^{3}$ Hospital Cayetano Heredia, Ministry of Health, Av. Honorio Delgado 262, San Martín de Porres, 31 Lima, Peru. ${ }^{4}$ Ministry of Health, Av. Salaverry 801, Jesús María, 15072 Lima, Peru. ${ }^{5}$ Department of Public Health, Ghent University, De Pintelaan 185, 9000 Ghent, Belgium.}

\section{Received: 9 February 2017 Accepted: 2 March 2018} Published online: 20 March 2018

\section{References}

1. WHO. Global tuberculosis report 2017. Geneva: World health organization; 2017. Disponible en: http://www.whoint/tb/publications/global_report/en/. Accessed 21 Feb 2018.

2. Mukadi YD, Maher D, Harries A. Tuberculosis case fatality rates in high HIV prevalence populations in sub-Saharan Africa. AIDS. 2001;15(2):143-52.

3. Zumla A, George A, Sharma V, Herbert RHN, Ilton BM, Oxley A, et al. The WHO 2014 global tuberculosis report-further to go. Lancet Glob Health. 2015;3(1):e10-2.

4. Panel on Opportunistic Infections in HIV-infected Adults and Adolescents. Guidelines for the prevention and treatment of opportunistic infections in HIV - infected adults and adolescents: recommendations from the Centers for Disease Control and Prevention, the National Institutes of Health, and the HIV Medicine Association of the Infectious Diseases Society of America. Available at http://aidsinfo.nih.gov/contentfiles/lvguidelines/adult_oi.pdf. Accessed May 12, 2015.

5. Bekker L-G, Wood RTB, co-infection HIV. When to start antiretroviral therapy. Contin med Educ 1 de noviembre de. 2011:29(10):420.

6. Blanc F-X, Sok T, Laureillard D, Borand L, Rekacewicz C, Nerrienet E, et al. Earlier versus later start of antiretroviral therapy in HIV-infected adults with tuberculosis. N Engl J Med. 20 de octubre de. 2011;365(16): 1471-81.

7. Havlir DV, Kendall MA, Ive P, Kumwenda J, Swindells S, Qasba SS, et al. Timing of antiretroviral therapy for HIV-1 infection and tuberculosis. N Engl J Med 20 de octubre de. 2011;365(16):1482-91.

8. Abdool Karim SS, Naidoo K, Grobler A, Padayatchi N, Baxter C, Gray AL, et al. Integration of antiretroviral therapy with tuberculosis treatment. N Engl J Med. 20 de octubre de. 2011;365(16):1492-501.

9. Branson BM, Handsfield HH, Lampe MA, Janssen RS, Taylor AW, Lyss SB, et al. Revised recommendations for HIV testing of adults, adolescents, and pregnant women in health-care settings. MMWR Recomm Rep. 2006;55(RR-14):1-17.

10. Sendagire I, Schreuder I, Mubiru M, van der Loeff MS, Cobelens F, KondeLule J, Low HIV. Testing rates among tuberculosis patients in Kampala, Uganda. BMC Public Health. 2010;10(1):177.

11. Bayer R, Edington C. HIV testing, human rights, and global AIDS policy: exceptionalism and its discontents. J Health Polit Policy Law. 2009;34(3): $301-23$.

12. Ministerio de Salud. Situación Epidemiológica de la Epidemia del VIH-SIDA en el Perú, al 31 de Diciembre del 2014. Boletín Epidemiológico (Lima). Volumen 24, Semana Epidemiológica №20. Del 17-23 de Mayo del 2015. Available at: http:/www.dge.gob.pe/portal/docs/vigilancia/boletines/2015/ 20.pdf/ Accessed 23 November, 2016.

13. Ministerio de Salud. Estrategia Sanitaria Nacional para la Prevención y Control de la Tuberculosis. Dirección General de Salud de las Personas. Norma Técnica de Salud para el Control de la Tuberculosis. Lima. Abril del 2006. Available at: ftp://ftp2.minsa.gob.pe/descargas/dgsp/ESN-tuberculosis/ normaspublicaciones/NTSTBC.pdf. Accesed 23 Nov 2016

14. WHO. Tuberculosis: Perfiles de países 2017. World Health Organization, Geneva; 2017. Disponible en: http://www.who.int/tb/country/data/profiles/ es/ Accessed 21 February, 2018.

15. Villegas L, Otero L, Sterling TR, Huaman MA, Van der Stuyft P, Gotuzzo E, Seas C. Prevalence, risk factors, and treatment outcomes of isoniazid- and rifampicin-mono-resistant pulmonary tuberculosis in lima, Peru. PLoS One. 2016;11(4):e0152933. https://doi.org/10.1371/journal.pone.0152933.

16. Lackey B, Seas C, Van der Stuyft P, Otero L. Patient characteristics associated with tuberculosis treatment default: a cohort study in a high-incidence area of lima, Peru. PLoS One. 2015;10(6):e0128541. https://doi.org/10.1371/journal. pone.0128541.

17. Alarcón Valentina, Alarcón Edith, Figueroa Cecilia, Mendoza-Ticona Alberto. Tuberculosis en el Perú: situación epidemiológica, avances y desafíos para su control. Rev. perú. med. exp. salud publica [Internet]. 2017 Abr [citado 2018 Feb 23] ; 34 ( 2 ): 299-310. Disponible en: http://www.scielo.org.pe/ scielo.php?script=sci_arttext\&pid=\$1726-46342017000200021\&lng=es. http:// dx.doi.org/https://doi.org/10.17843/rpmesp.2017.342.2384.

18. Ministerio de Salud. Estrategia Sanitaria Nacional para la Prevención y Control de la Tuberculosis. 2013. Dirección General de Salud de las Personas. Norma Técnica de Salud para el Control de la Tuberculosis. Lima del 2013. Available at: ftp://ftp2.minsa.gob.pe/normaslegales/2013/RM715_ 2013_MINSA.pdf. Accessed 23 Nov, 2016.

19. Ministerio de Salud. Estrategia Sanitaria Nacional Prevención y control de Infecciones de Transmisión Sexual y VIH-SIDA. Dirección General de Salud de las Personas. Norma Técnica de manejo de Antiretrovirales y reacciones adversas para el médico de atención integral de las personas viviendo con VIH/SID. In: Alima; 2004. Available at: http://www.minsa.gob.pe/ transparencia/index.asp?op=115.

20. Ministerio de Economía y Finanzas, Perú. Sistema de Folalización de Hogares Available: http://www.sisfoh.gob.pe/. Accessed 24 May 2014.

21. Ewing JA. Detecting alcoholism: the CAGE questionnaire. JAMA. 1984; 252(14):1905.

22. Ministerio de Salud Análisis de la Situación Epidemiológica del VIH/SIDA en el Perú 2013. Dlrección General de Epidemiología. Lima, Noviembre 2013. Available at: http://www.dge.gob.pe/portal/docs/ASISVIH2013.pdf. Accessed 23 November, 2016.

23. Engelbrecht MC, Heunis JC, Kigozi NG. The views of primary health care nurses on HIV counseling and testing for tuberculosis patients in two districts of the free State Province in South Africa. Afr J Nurs Midwifery. 2008;10:70-83.

24. Achanta S, Kumar AMV, Nagaraja SB, Jaju J, Shamrao SRM, Uppaluri R, et al. Feasibility and effectiveness of provider initiated HIV testing and counseling of TB suspects in Vizianagaram district, South India. PLoS One. 2012;7(7): e41378.

25. Kigozi NG, Heunis JC, Wouters E, van den Berg HS. Tuberculosis patients' reasons for, and suggestions to address non-uptake of HIV testing: a crosssectional study in the free State Province, South Africa. BMC Health Serv Res. 2011;11:110.

26. Palanivel C, Kumar AMV, Mahalakshmi T, Govindarajan S, Claassens M, Satyanarayana S, et al. Uptake of HIV testing and HIV positivity among presumptive tuberculosis patients at Puducherry, South India. Public Health Action. 2013;3(3):220-3.

27. Yi S, Poudel KC, Yasuoka J, Ichikawa M, Tan V, Jimba M. Influencing factors for seeking HIV voluntary counseling and testing among tuberculosis patients in Cambodia. AIDS Care. 2009;21(4):529-34.

28. V G Maziel J, Segura ER, Salazar C V, Valverde A R, Salazar L X, et al. Percepciones de las personas viviendo con VIH/SIDA sobre los servicios de salud y el tratamiento antirretroviral de gran actividad: un estudio transversal en cinco ciudades del Perú. Rev Peru Med Exp Salud Pública 2007;24(3):211-217.

29. Orne-Gliemann J, Larmarange J, Boyer S, Iwuji C, McGrath N, Bärnighausen T, et al. Addressing social issues in a universal HIV test and treat intervention trial (ANRS 12249 TasP) in South Africa: methods for appraisal. BMC Public Health. 2015;15:209.

30. Iwuji CC, Orne-Gliemann J, Larmarange J, Okesola N, Tanser F, Thiebaut R, et al. Uptake of home-based HIV testing, linkage to care, and community attitudes about ART in rural KwaZulu-Natal, South Africa: descriptive results from the first phase of the ANRS 12249 TasP cluster-randomised trial. PLoS Med. 2016;13(8):e1002107.

31. Bwire R, Nagelkerke NJD, Borgdorff MW. Finding patients eligible for antiretroviral therapy using TB services as entry point for HIV treatment. Tropical Med Int Health. 2006;11(10):1567-75.

32. Denegetu AW, Dolamo BL. HIV screening among TB patients and cotrimoxazole preventive therapy for TB/HIV patients in Addis Ababa: facility based descriptive study. PLoS One. 2014;9(2):e86614.

33. Charles MK, Lindegren ML, Wester CW, Blevins M, Sterling TR, Dung NT, et al. Implementation of tuberculosis intensive case finding, isoniazid 
preventive therapy, and infection control («three l's») and HIV-tuberculosis service integration in lower income countries. Ivanyi J. PLoS One. 2016;11(4): e0153243.

34. Legido-Quigley $\mathrm{H}$, Montgomery CM, Khan P, Atun R, Fakoya A, Getahun H, et al. Integrating tuberculosis and HIV services in low- and middle-income countries: asystematic review. Tropical Med Int Health. 2013;18(2):199-211.

35. Seyoum A, Legesse M. Knowledge of tuberculosis (TB) and human immunodeficiency virus (HIV) and perception about provider initiated HIV testing and counseling among TB patients attending health facilities in Harar town, eastern Ethiopia. BMC Public Health. 2013;13:124.

Submit your next manuscript to BioMed Central and we will help you at every step:

- We accept pre-submission inquiries

- Our selector tool helps you to find the most relevant journal

- We provide round the clock customer support

- Convenient online submission

- Thorough peer review

- Inclusion in PubMed and all major indexing services

- Maximum visibility for your research

Submit your manuscript at www.biomedcentral.com/submit 